\title{
Effect of fertigation on quality of curry leaf (Murraya koenigii Spreng)
}

\begin{abstract}
A field experiment on effect of high density planting on quality of curry leaf was conducted at Department of Spices and Plantation Crops, Horticultural College and Research Institute, Tamil Nadu Agricultural University, Periyakulam during 201113. The experiment was layed out in randomized block design with six treatments. Biometrical observations were made from randomly selected five plants and were subjected to statistical analysis. The result reveled that, among the six levels of fertilizers the highest essential oil $(0.187$ percent), ascorbic acid content $(3.8 \mathrm{mg} / 100 \mathrm{~g})$, crude protein content ( 5.7 percent), Iron content (3.48 percent) and Shelf life (3.21days) was recorded $\mathrm{T}_{6}$ - application of $100 \% \mathrm{RDF}$ through fertigation respectively.
\end{abstract}

Keywords: Curry leaf, quality, essential oil, protein
Volume 2 Issue 6 - 2018

\author{
Jagadeeshkanth RP,' R Sankaranarayanan, ${ }^{2} \mathrm{~V}$ \\ Suresh ${ }^{3}$ \\ 'Assistant Professor, Imayam Institute of Agriculture and \\ Technology, India \\ ${ }^{2}$ Professor, Department of fruit crops, Horticultural College and \\ Research Institute, India \\ ${ }^{3}$ Assistant Professor, RVS Padmavathy College of Horticultural, \\ India
}

Correspondence: Jagadeeshkanth RP,Assistant Professor, Imayam Institute of Agriculture and Technology, Thuraiyur, Trichy District, India, Email jagakanth@gmail.com

Received: October 03, 2018 | Published: December 19, 2018

\section{Introduction}

Curry leaf (Murraya koenigii Spreng.) belongs to the family Rutaceae. It is an attractive medium sized tree and maintained as a small shrub reaching a height of 1.0 to $1.5 \mathrm{~m}$. It is grown commercially for its aromatic spicy green leaves and it is propagated through seeds from selected mother plants. ${ }^{1}$ In Tamil Nadu, as there is no released variety in curry leaf, farmers prefer the popular local variety viz., 'Senkaampu' an ideotype grown in different parts of Tamil Nadu especially in Karamadai tract of Coimbatore district. The petiole is purplish red in colour. The leaves have good aroma and flavour due to high essential oil content. Presently it is largely cultivated under organic manures. ${ }^{2}$ However, inorganic fertilizers are applied at the rate of $100 \mathrm{~g}$ of NPK mixture per plant after every pruning which is generally followed before supplemental irrigation after monsoon showers. In general, three crops are harvested in a year with 3-4 months interval. The winter season generally fetches very good market price since the leaf production is very limited in this season. Umesha et al. ${ }^{3}$ reported that $\mathrm{P}$ had no significant effect on either growth or yield parameters of clocimum. The results of six croppings over a period of two years showed that nitrogen and potassium significantly influenced the leaf area, dry matter accumulation and leaf yield. While application of $150 \mathrm{~kg}$ nitrogen per hectare significantly influenced the essential oil (114.30kg/ha) and eugenol yield $(92.28 \mathrm{~kg} / \mathrm{ha})$, and the application of $75 \mathrm{~kg} \mathrm{~K} 2 \mathrm{O}$ per hectare improved the yield and yield parameters significantly. But $\mathrm{P}_{2} \mathrm{O}_{5}$ had no significant effect on growth and yield of clocimum.

\section{Materials and methods}

A field experiment on effect of fertigation on quality of curry leaf was conducted at Department of Spices and Plantation Crops, Horticultural College and Research Institute, Tamil Nadu Agricultural University, Periyakulam during 2011-13 (Table 1).

Data on leaf quality as essential oil (per cent), ascorbic acid content $(\mathrm{mg} / 100 \mathrm{~g})$, crude protein content (per cent), Iron content (per cent) and Shelf life (days) was recorded. The data were subjected to statistics analysis as the method suggested by Panse and Sukhatme. ${ }^{4}$

Table I The experiment was laid out in a randomized block design with six treatments as follows

\begin{tabular}{ll}
\hline Treatments & Treatment details \\
\hline$T_{1}$ & Without fertilizer application \\
$T_{2}$ & $100 \%$ of $N, P, K$ as soil application \\
$T_{3}$ & $75 \%$ of $N, P, K$ as soil application $+25 \%$ of fertigation \\
$T_{4}$ & $50 \%$ of $N, P, K$ as soil application $+50 \%$ of fertigation \\
$T_{5}$ & $25 \%$ of N,P, K as soil application $+75 \%$ of fertigation \\
$T_{6}$ & $100 \%$ of fertigation \\
\hline
\end{tabular}

\section{Result and discussion}

The application of nutrients through fertigation significantly influenced the essential oil content. The maximum essential oil content was recorded $\mathrm{T}_{6}$-application of $100 \% \mathrm{RDF}$ through fertigation $(0.187 \%)$ it was closely followed by $\mathrm{T}_{5}-25 \%$ of $\mathrm{N}, \mathrm{P}, \mathrm{K}$ as soil application $+75 \%$ of fertigation $(0.171 \%)$ compared to minimum recorded in $\mathrm{T}_{1}$-without fertilizer application $(0.134 \%)$ followed by $\mathrm{T}_{2}$ $-100 \%$ of N,P,K as soil application $(0.136 \%)$ and $\mathrm{T}_{3}-75 \%$ of $\mathrm{N}, \mathrm{P}, \mathrm{K}$ as soil application $+25 \%$ of fertigation $(0.137 \%)$.

The application of nutrients through fertigation significantly influenced the ascorbic acid content. It ranged from $2.5 \mathrm{mg} / 100 \mathrm{~g}$ to $3.8 \mathrm{mg} / 100 \mathrm{~g}$. The maximum ascorbic acid content was recorded $\mathrm{T}_{6}-$ application of $100 \%$ RDF through fertigation $(3.8 \mathrm{mg} / 100 \mathrm{~g})$ it was closely followed by $\mathrm{T}_{5}-25 \%$ of N,P,K as soil application $+75 \%$ of fertigation $(3.5 \mathrm{mg} / 100 \mathrm{~g})$ compared to minimum recorded in $\mathrm{T}_{-}-$ without fertilizer application $(2.5 \mathrm{mg} / 100 \mathrm{~g})$ followed by $\mathrm{T}_{2}-100 \%$ of $\mathrm{N}, \mathrm{P}, \mathrm{K}$ as soil application $(2.8 \mathrm{mg} / 100 \mathrm{~g})$.

The application of nutrients through fertigation significantly influenced the crude protein content. It ranged from $4.2 \%$ to $5.7 \%$. The 
maximum crude protein content was recorded $\mathrm{T}_{6}$ - application of $100 \%$ RDF through fertigation (5.7\%) it was closely followed by $\mathrm{T}_{5}-25 \%$ of $\mathrm{N}, \mathrm{P}, \mathrm{K}$ as soil application $+75 \%$ of fertigation (5.4\%) compared to minimum recorded in $\mathrm{T}_{1}$-without fertilizer application $(4.2 \%)$ followed by $\mathrm{T}_{2}-100 \%$ of $\mathrm{N}, \mathrm{P}, \mathrm{K}$ as soil application (4.4\%).

The effect of fertigation on Iron content of the curry leaf are furnished. The application of nutrients through fertigation significantly influenced the Iron content.. The maximum iron content was recorded $\mathrm{T}_{6}$ - application of $100 \%$ RDF through fertigation (3.48\%) it was closely followed by $\mathrm{T}_{5}-25 \%$ of $\mathrm{N}, \mathrm{P}, \mathrm{K}$ as soil application $+75 \%$ of fertigation $(3.31 \%)$ and $\mathrm{T}_{4}-50 \%$ of $\mathrm{N}, \mathrm{P}, \mathrm{K}$ as soil application $+50 \%$ of fertigation $\left(3.28 \%\right.$ ) compared to minimum recorded in $\mathrm{T}_{1}$-without fertilizer application (3.16\%) followed by $\mathrm{T}_{2}-100 \%$ of N,P,K as soil application $(3.17 \%)$ and $\mathrm{T}_{3}-75 \%$ of $\mathrm{N}, \mathrm{P}, \mathrm{K}$ as soil application $+25 \%$ of fertigation $(3.21 \%)$. The application of nutrients through fertigation significantly influenced on the shelf life of fresh curry leaves both unpacked and packed condition. shelf life of curry leaves under unpacked condition significantly varied from 1.56 days to 3.21 days. The maximum shelf life was recorded $\mathrm{T}_{6}$-application of $100 \% \mathrm{RDF}$ through fertigation (3.21 days) it was closely followed by $\mathrm{T}_{5}-25 \%$ of $\mathrm{N}, \mathrm{P}, \mathrm{K}$ as soil application $+75 \%$ of fertigation ( 2.65 days) compared to minimum recorded in $\mathrm{T}_{1}$-without fertilizer application (1.56days) followed by $\mathrm{T}_{2}-100 \%$ of $\mathrm{N}, \mathrm{P}, \mathrm{K}$ as soil application (2.12 days) (Table 2-4).

Table 2 Effect of fertigation on essential oil (per cent) and ascorbic acid content $(\mathrm{mg} / \mathrm{l} 00 \mathrm{~g})$ in curry leaf

\begin{tabular}{lll}
\hline Treatments & $\begin{array}{l}\text { Essential oil } \\
\text { (per cent) }\end{array}$ & Ascorbic acid content (mg/ / 00g) \\
\hline $\mathbf{T}_{1}$ & 0.134 & 2.5 \\
$\mathbf{T}_{2}$ & 0.136 & 2.8 \\
$\mathbf{T}_{3}$ & 0.137 & 3.1 \\
$\mathbf{T}_{4}$ & 0.165 & 3.3 \\
$\mathbf{T}_{5}$ & 0.171 & 3.5 \\
$\mathbf{T}_{6}$ & 0.187 & 3.8 \\
Mean & 0.1546 & 3.1654 \\
$\mathbf{S E d}$ & 0.0036 & 0.0467 \\
CD (0.05) & 0.0076 & 0.0996 \\
\hline
\end{tabular}

Table 3 Effect of fertigation on crude protein content (per cent) and Iron content (per cent) in curry leaf

\begin{tabular}{lll}
\hline Treatments & $\begin{array}{l}\text { Crude protein content } \\
\text { (per cent) }\end{array}$ & Iron content (per cent) \\
\hline $\mathbf{T}_{1}$ & 4.2 & 3.16 \\
$\mathbf{T}_{2}$ & 4.4 & 3.17 \\
$\mathbf{T}_{3}$ & 4.9 & 3.21 \\
$\mathbf{T}_{4}$ & 5.2 & 3.28 \\
$\mathbf{T}_{5}$ & 5.4 & 3.31 \\
$\mathbf{T}_{6}$ & 5.7 & 3.48 \\
Mean & 4.96 & 3.26 \\
$\mathbf{S E d}$ & 0.07 & 0.04 \\
$\mathbf{C D}(\mathbf{0 . 0 5 )}$ & 0.15 & 0.09 \\
\hline
\end{tabular}

Table 4 Effect of fertigation on Shelf life (days) in curry leaf

\begin{tabular}{lll} 
Treatments & $\begin{array}{l}\text { Shelf life unpacked } \\
\text { condition (days) }\end{array}$ & $\begin{array}{l}\text { Shelf life with five } \\
\text { per cent ventilation }\end{array}$ \\
\hline $\mathbf{T}_{1}$ & 1.56 & 2.50 \\
$\mathbf{T}_{2}$ & 2.12 & 2.90 \\
$\mathbf{T}_{3}$ & 2.21 & 3.00 \\
$\mathbf{T}_{4}$ & 2.51 & 3.50 \\
$\mathbf{T}_{5}$ & 2.65 & 3.67 \\
$\mathbf{T}_{6}$ & 3.21 & 3.98 \\
Mean & 2.375 & 3.257 \\
$\mathbf{S E d}$ & 0.033 & 0.047 \\
$\mathbf{C D}(\mathbf{0 . 0 5 )}$ & 0.071 & 0.1006
\end{tabular}

The effect of fertigation on essential oil content of fresh leaves showed that it was highly influenced by the treatments. Application of $100 \%$ RDF through fertigation were found to record the highest values of essential oil content. The possible reason for quality improvement due to drip fertigation might be due to supply of sufficient quantity of nitrogen, which was essential compound in many amino acids and lipids associated with oil production. Increased the essential oil content of fresh curry leaf and the quality improvement might be due to more number of leaves, increased leaf area and specific leaf weight which consequently would have increased the number of oil glands resulting in higher oil content. Similar influences were also reported by Panduranga shenoy ${ }^{5}$ in davana (Artemisia pallens Wall.). Krishnamoorthy, ${ }^{6}$ Arularasu ${ }^{7}$ in Ocimum sanctum.

In any production system, the primary goal is to achieve maximum yield per unit area without affecting the quality. In the present investigation $100 \%$ RDF through fertigation registered highest ascorbic acid content. This is in agreement with the findings of Prabhu ${ }^{8}$ in paprika. This led to higher concentration of NPK in leaves and resulted in better accumulation of assimilates. This in agreement with Balakrishnan et al. ${ }^{9}$ The shelf life of curry leaves was recorded to be the highest in the curry leaf plants $100 \%$ RDF through ferigation under unpacked condition. The curry leaves packed in polythene bag with five per cent ventilation was found to be remaining the same in the best treatment of $100 \%$ RDF through fertigation. Possible reason for the improvement of shelf life of fresh curry leaves harvested from crop subjected to drip fertigation might have higher and continuous uptake of potassium nutrients from fertigation throughout the crop season. It would have led to long shelf life through increased dry matter content. Optimum level of potassium helped in greater translocation of metabolites to storage organs and enhanced thickening of leaves. Thus efficient metabolism and better source sink relationship might have contributed on improved storage life of curry leaves. These results were in accordance with findings of Madan \& Sandhu ${ }^{10}$ in white onion. Potassium nutrition imparts sturdiness to the leaf tissues by increasing thickness of cell wall and helped in getting healthy leaves. Further, the strong peel of leaf would have protected them against decay and the reduced rate of respiration during storage. ${ }^{11}$

Ryall \& Lipton ${ }^{12}$ reported that the use of plastic films for packaging the produce provides a high relative humidity around the commodity and results in lower water losses from it. The use of polythene films had been studied in asparagus and beneficial effects were obtained, 
especially, when small perforated areas were allowed for minimal ventilation as reported by Lill. ${ }^{13}$

\section{Acknowledgments}

None.

\section{Conflicts of interest}

Author declares that there is no conflicts of interest.

\section{References}

1. Abraham VA. Indian Spices: The Legacy, Production and Processing of India's. Spice India. 1991;(4):13-14.

2. Goudra, BK, BB Madalagiri. Effect of nitrogen nutrition on yield and yield component of curry leaf (Murraya koenigii Spreng). Indian Cocoa, Arecanut Spices J. 1992;16(2):66-68.

3. Umesha K, KM Bojappa NS. Suresh AA. et al. Herb, oil and eugenol yield of clocimum (Ocimum gratissimum L.) in relation to levels of nitrogen, phosphorus and potassium application. Indian Perfumer. 1968;37(4):311-314.

4. Panse, VG, PV Sukhatme. Statistical methods for agricultural works. Fourth Edn.,ICAR, New Delhi. 1985.

5. Panduranga Shenoy K. Studies on the effect of nutrients and cycocel on growth and yield of davana (Artemisia pallens wall.), University of Agricultural Sciences, Bangalore; 1980.
6. Krishnamoorthy R. Studies on the effect of nitrogen, phosphorus and potassium on growth, her bage yield and essential oil production in Davana (Artemesia pallens wall.) University of Agricultural Sciences. Bangalore; 1985.

7. Arularasu P. Effect of graded doses of nitrogen and spacing on growth and yield of herbage and oil in Tulsi (Ocimum sanctum L.). TNAU, Coimbatore; 1995.

8. Prabhu T. Standardisation of fertigation techniques in paprika (Capsicum annuum var. longum L.) under open and coconut shade conditions. Submitted to Tamil Nadu Agri. Univ. Coimbatore; 2007.

9. Balakrishnan K, K Venkatesan, S Sambandamurthi. Effect of foliar application of $\mathrm{Zn}, \mathrm{Fe}, \mathrm{Mn}$ and $\mathrm{B}$ on yield and quality of pomegranate cv. Ganesh. The Orissa J Hort. 1996;24:33-35.

10. Madan, PS, S Sandhu. Studies on the storage behaviour of white onion (Allium cepa L.) variety as influenced by levels of N, P and K. Haryana Agric Univ J Res. 1983;13(3):433-438.

11. SankarV. Studies on organic farming practices and post harvest technology in onion (Allium cepa var.cepa L.) for the production of export quality bulbs, phd. (Hort.) Thesis, Tamil Nadu Agricultural University, Coimbatore; 2004.

12. Ryall AL, WJ Lipton. Handling, transportation and storage of fruits and vegetables, 2nd edition. Vegetables and melons. AVI Publishing Company. USA; $1979 ; 587$.

13. Lill RE. Storage of fresh asparagus. J Exptl Agri. 1980;2:163-167. 